DOI: https://doi.org/10.24144/2409-6857.2020.2(56).46-51

УДК 338.48

\author{
Слава С.С., Чиняк В.В., Пугінська В.В.
}

\title{
КОМПОНЕНТНО-СТРУКТУРНЕ ГРУПУВАННЯ ПАРАМЕТРІВ СФЕРИ ГОСТИННОСТІ
}

\begin{abstract}
Проаналізовано та порівняно дефініцію термінів «гостинність» та «індустрія гостинності», які пропонують різні автори. Розглянуто основні фактори, які впливають на розвиток сучасної індустрії гостинності. Запропоновано групування складників сфери гостинності на основі їх належності до певних груп. Зроблено кількісний розподіл складових елементів сектору гостинності. Подано порівняння процесної структури індустрї гостинності та компонентних складових туризму. Сформовано висновки щчодо факторів впливу та різноманітних тлумачень понять «індустрія гостинності» та «гостинність».
\end{abstract}

Ключові слова: індустрія гостинності, туризм, готельний бізнес, фактори впливу.

Постановка проблеми. В останні роки міжнародний туризм набув стрімких темпів розвитку, перетворившись в одну з найбільших і високоприбуткових галузей світового господарства. На його частку припадає 7\% загального обсягу інвестицій, $5 \%$ усіх податкових надходжень і третину світової торгівлі послугами. Міжнародний туризм має великий вплив на такі ключові сектори економіки, як транспорт i зв'язок, торгівля, будівництво, сільське господарство, виробництво товарів народного споживання, виступаючи каталізатором соціально-економічного розвитку. Він забезпечує зайнятість понад 250 млн осіб, тобто кожного восьмого працівника в світі [1].

Якщо уявити індустрії туризму і гостинності як складний, багатокомпонентний процес обслуговування споживачів, то роль і значення факторів, які визначають загальний напрям розвитку чи специфіку окремих рис сектору гостинності, стають важливими і очевидними [3. c. 35] .

Поняття «індустрія гостинності» та «гостинність» розглядалися в роботах багатьох авторів, їм були дані численні визначення, що відображали сутність даних дефініцій. Але пита-

(C) Слава С.С., к.е.н.,доц., професор кафедри економіки i підприємництва економічного факультету, ДВНЗ «Ужгородський національний університет», E-mail: svitlana.slava@uzhnu.edu.ua Чиняк В.В., аспірант кафедри економіки i підприємництва, ст. лаборант кафедри фізичної географії та раціонального природокористування, ДВНЗ «Ужгородський національний університет», E-mail:vitalia.chyniak@uzhnu.edu.ua Пугінська В. В., аспірант кафедри економіки і підприємництва, ДВНЗ «Ужгородський національний університет», E-mail: vladochka.ripych@gmail.com ння специфічного групування параметрів сфери гостинності на основі їх належності до груп певної типології, все ще недостатньо розглянуті, тому дане дослідження присвячене саме цим питанням. Воно має на меті виявити, які складники сфери гостинності займають провідне місце при формуванні власне індустрії гостинності на певній території.

Виходячи з того, що фактори, які впливають на складники індустрії гостинності $є$ важливими елементами і для розвитку сучасних готельних підприємств, тому прогнозування їх впливу набуває особливої актуальності.

Аналіз останніх досліджень і публікацій. Дослідження основних факторів впливу на розвиток сфери гостинності та туризму розглянуті в працях національних і закордонних вчених, таких як: Джанджугазова Є.А.[3], в іiі роботах представлені сучасні концепції маркетингу в індустрії гостинності. Виклад теоретичних питань органічно переплітається із прикладами із практики роботи підприємств індустрії гостинності. В навчальному посібнику Д.І. Єлканової, Д.А. Осипова, В.В. Романова, С.В. Сорокіна [4] запропоновано розкриття сутності індустрії гостинності і іiі складових. Проаналізовано сучасний стан складників індустрії гостинності. В роботах Р. Браймера [5] розглядаються сучасні проблеми готельного господарства та туристичного бізнесу. Б. Л. Соловйов, Л. А. Толстова [7] розглядають основні завдання та проблеми менеджменту індустрії гостинності. Кусков А.С. [2] описує готельне господарство як одну із найважливіших галузей туристичної індустрії. В довіднику Квартальнова B.O., I. В. Зоріна [6] містяться розгорнуті характеристики термінів і понять, прийнятих у вітчизняному та зарубіжному туризмі, висвітлюються історичні аспекти і сучасні тенденції розвитку індустрії туризма.

Основні чинники розвитку, що впливають на 
розвиток індустрії гостинності достатньо широко представлені в літературних джерелах. Проте у зв'язку iз прискореними темпами розвитку міжнародного туризму в цілому та розширення сфери гостинності в Україні зокрема, актуальність дослідження та виявлення факторів впливу на ці галузі є високою.

Формулювання цілей статті. Метою статті $\epsilon$ огляд, характеристика та структуризація різноманітних факторів впливу, що сприяють розвитку індустрії гостинності на сучасному етапі, а також порівняння визначень термінів «гостинність» та «індустрія гостинності».

Опис основного матеріалу дослідження. Визначення понять «гостинність» та «індустрія гостинності» автори дають по-різному.

Більшість авторів схиляються до такого визначення, що індустрія гостинності являє собою збірне поняття для багаточисленних i різноманітних форм підприємництва, яке спеціалізується на ринкові послуг, пов'язаних 3 прийомом і обслуговуванням гостей [5. с. 3]. Також це комплексна сфера діяльності працівників, які задовільняють будь-які потреби і побажання туристів [4. с. 1].

Гостинністю $є$ гармонічне поєднання виробництва туристичних послуг, комфортності середовища відпочинку i люб'язної поведінки обслуговуючого персоналу в цілях задоволення потреб гостей при гарантіях їх безпеки, фізичного та психологічного комфорту. Гостинність найважливіша споживча властивість туристського продукту: уміння дати відчути клієнту, що йому раді, 3 достоїнством продемонструвати йому повагу, бути люб'язним [6. с. 21].

Поняття "індустрія гостинності" настільки ж багатогранне i, відповідно, складне для визначення, як і поняття "гостинність" [6. с. 55]. Гостинність - найперша і найголовніша справа для людини. Гостинність це філософія поведінки, але індустрія це вже сервіс за винагороду [2. с. 2].

Індустрія гостинності - це сфера підприємництва, яка складається 3 таких видів обслуговування, які опираються на принципи гостинності, що характеризуються щедрістю та дружелюбністю стосовно гостей [2. с. 2].

Склад секторів, які входять власне у сферу гостинності важко окреслити однозначно. На думку Дж. Діттмера та Дж. Гріффіна у структуру індустрії гостинності входять власне гостинність, а також подорожі та туризм [8., с. 11].

Загалом структурне групування компонентів, які формують сферу гостинності, здійснено на основі того, яку різницю вбачають науковці у тлумаченні даних термінів (табл.1).

Таблиця 1.

Структурне групування компонентів-складових сфери гостинності $[5,4,6,7,3,11,9,10,8]$

\begin{tabular}{|c|c|c|c|c|}
\hline Автори & Фізичні & Економічні & $\begin{array}{l}\text { Організаційні та сервісні } \\
\text { навики персоналу }\end{array}$ & Безпека \\
\hline Р. Браймер [5] & & $\begin{array}{l}\text { Індустрія, } \\
\text { форма } \\
\text { обслуговування, } \\
\text { ринкові послуги }\end{array}$ & $\begin{array}{l}\text { Прийом і обслуговування } \\
\text { гостей } \\
\text { Турбота про гостя }\end{array}$ & \\
\hline $\begin{array}{l}\text { Д.І. Слканова } \\
\text { Д.А. Осипов } \\
\text { В.В. Романов } \\
\text { Є.В. Сорокіна [4] }\end{array}$ & & $\begin{array}{l}\text { Індустрія, } \\
\text { сфера діяльності } \\
\text { Використання } \\
\text { сучасних досягнень } \\
\text { прогресу }\end{array}$ & $\begin{array}{l}\text { Задоволення } \\
\text { будь-яких потреб і побажань } \\
\text { туристів }\end{array}$ & \\
\hline $\begin{array}{l}\text { I. В. Зорін } \\
\text { В.А.Квартальнов } \\
\text { [6] }\end{array}$ & $\begin{array}{l}\text { Комфортність } \\
\text { середовища } \\
\text { відпочинку }\end{array}$ & $\begin{array}{l}\text { Виробництво } \\
\text { туристичних послуг }\end{array}$ & $\begin{array}{l}\text { Люб’язна поведінка } \\
\text { обслуговуючого персоналу } \\
\text { Задоволення потреб гостей для } \\
\text { фізичного та психологічного } \\
\text { комфорту } \\
3 \text { достоїнством демонструвати } \\
\text { клієнту повагу }\end{array}$ & $\begin{array}{l}\text { Гарантія } \\
\text { безпеки } \\
\text { туристів }\end{array}$ \\
\hline Г. Пейдж & & $\begin{array}{l}\text { Індустрія, } \\
\text { сервіс за } \\
\text { винагороду }\end{array}$ & Філософія поведінки & \\
\hline Н. Уебстер & & $\begin{array}{l}\text { Сфера } \\
\text { підприємництва } \\
\text { Вид обслуговування }\end{array}$ & $\begin{array}{l}\text { Щедрість та дружелюбність } \\
\text { стосовно гостей }\end{array}$ & \\
\hline $\begin{array}{l}\text { Б. Л. Соловйов } \\
\text { Л. А. Толстова [7] }\end{array}$ & & & "Споживач завжди правий!" & \\
\hline
\end{tabular}




\begin{tabular}{|c|c|c|c|c|}
\hline Автори & Фізичні & Економічні & $\begin{array}{l}\text { Організаційні та сервісні } \\
\text { навики персоналу }\end{array}$ & Безпека \\
\hline $\begin{array}{l}\text { Е.А.Джанджугазова } \\
\text { [3] }\end{array}$ & & $\begin{array}{l}\text { Сдність всіх } \\
\text { співпрацюючих } \\
\text { один } 3 \text { одним фірм } \\
\text { та організацій } \\
\text { Ряд секторів }\end{array}$ & Задоволення потреб гостей & \\
\hline $\begin{array}{l}\text { Дж. Діттмер } \\
\text { Дж. Гріффін [11] }\end{array}$ & & $\begin{array}{l}\text { Подорожі і туризм } \\
\text { Сектор розміщення } \\
\text { Продовольчий } \\
\text { сектор } \\
\text { Транспорт } \\
\text { Турагентсва } \\
\text { Туроператори }\end{array}$ & $\begin{array}{l}\text { Гостинність } \\
\text { Розваги та відпочинок }\end{array}$ & \\
\hline $\begin{array}{l}\text { Чудновський А.Д., } \\
\text { М.А. Жукова, Н.А. } \\
\text { Зайцева [9] }\end{array}$ & $\begin{array}{l}\text { Інфраструктура } \\
\text { туризму }\end{array}$ & $\begin{array}{l}\text { Сукупність } \\
\text { загальних умов } \\
\text { виробництва } \\
\text { туристського } \\
\text { продукту }\end{array}$ & & \\
\hline $\begin{array}{l}\text { Воронкова Л.П. } \\
\text { [10] }\end{array}$ & $\begin{array}{l}\text { Сукупність } \\
\text { засобів } \\
\text { розміщення, } \\
\text { харчування і } \\
\text { розваг туристів }\end{array}$ & & $\begin{array}{l}\text { Традиції зустрічі гостей в } \\
\text { різних культурах }\end{array}$ & \\
\hline $\begin{array}{l}\text { Ф. Котлер, Боуэн } \\
\text { Д., Мейкенз Д. [8] }\end{array}$ & $\begin{array}{l}\text { Проживання, } \\
\text { харчування }\end{array}$ & Бізнес & $\begin{array}{l}\text { Організація дозвілля туристів } \\
\text { Задоволення потреб клієнта }\end{array}$ & ' \\
\hline $\begin{array}{l}\text { Сумарна кількість } \\
\text { неповторюваних } \\
\text { факторів (32) }\end{array}$ & 5 & 16 & 10 & 1 \\
\hline
\end{tabular}

До внутрішніх чинників, що впливають на сферу гостинності належать: здібності керівників підприємств індустрії гостинності керувати в умовах сучасного ринку, інноваційна політика підприємств, створення сприятливого іміджу та соціально-психологічного клімату (економічні складники), культурні фактори (організаційні та сервісні навички персоналу), стан розвитку інфраструктури (фізичні складники), фактор безпеки подорожей. Саме ці фактори мають найбільший вплив на формування індустрії гостинності в певному регіоні чи державі.

Зовнішні фактори здійснюють більш опосередкований вплив на діяльність підприємств, що надають послуги гостинності (стан банківської системи, науково-технологічні фактори тощо).

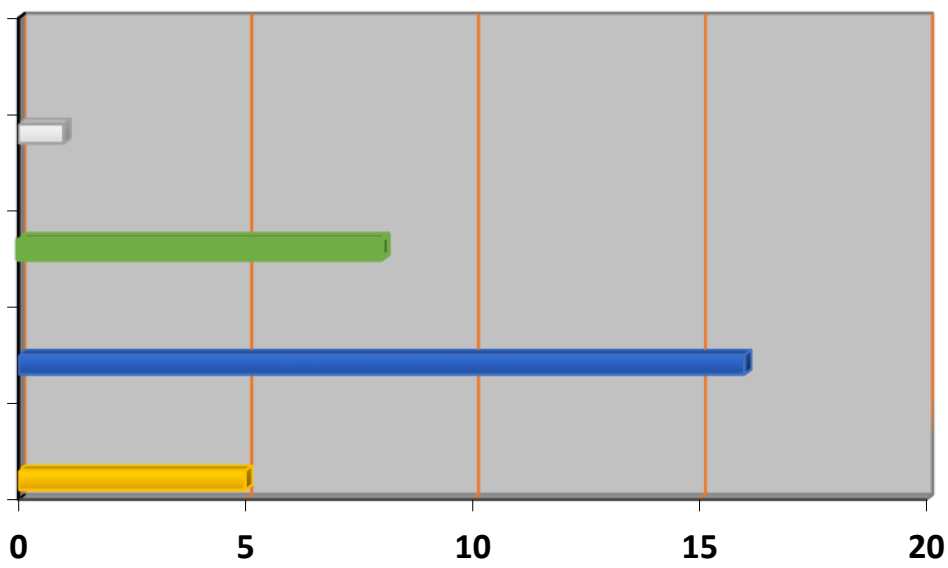

$\square$ Фактор безпеки

Організаційні та сервісні навики персоналу

Економічні складники

Фізичні складники

\section{Рис.1 Розподіл складників сфери гостинності*}

*Джерело: сформовано на основі Таблиці 1 
Загалом визначення «індустрія гостинності» та «індустрія туризму» не $\epsilon$ тотожними проте мають багато спільних рис. Автори по-різному трактують їх співвідношення. На нашу думку, це питання розглядається двояко, адже на разі, 3 однієї точки зору поняття «туризм» включає в себе задоволення потреб клієнтів, організацію їх відпочинку та дозвілля, тобто перебирає на себе функції сфери гостинності. 3 іншої сторони, «індустрія гостинності» - ширше визначення, більш загальне і ємне, воно включає в себе не тільки задоводення потреб туристів або мандрівників у вузькому сенсі, а взагалі всіх потенційних споживачів, що перебувають на території закладу сфери гостинності.

Всі туристичні гілки об' єднуються тим, що для ïх безперервного і ритмічного росту і розвитку необхідна відповідна інфраструктура, яку забезпечують заклади індустрії гостинності. Відповідно до цієї точки зору саме сфера гостинності $€$ фундаментом для розвитку різних напрямків туристичних потоків.

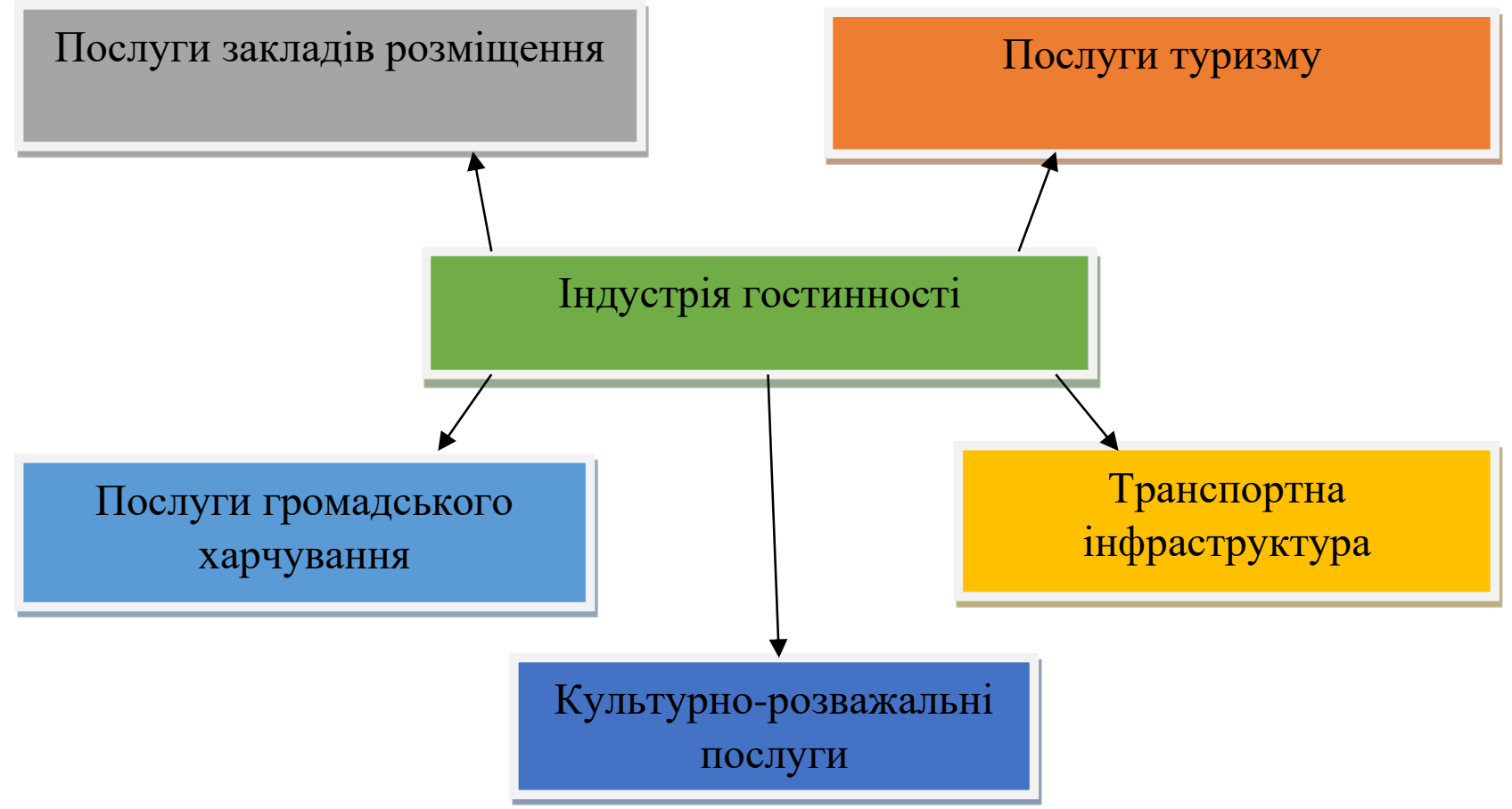

\section{Рис. 2 Процесна структура індустрії гостинності $[3,5,10]$}

Поряд 3 цим існує інша класифікація, яка розглядає саме туризм як комплексну основу для розвитку всіх похідних компонентів. На рисунку 3 відображено складові туризму в цілому, якщо розглядати його як першооснову для розвитку його похідних елементів (організації індустрії туризму, індустрія гостинності тощо).

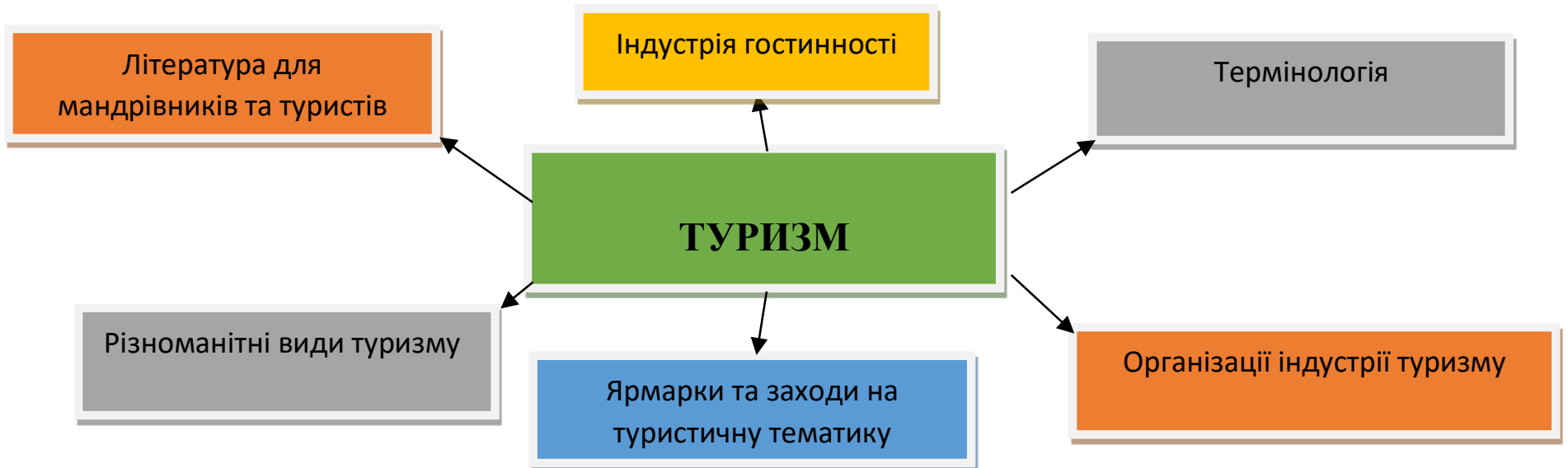

Рис. 3. Компонентні складові туризму $[1,6,8]$ 
Різноманітні види туризму потребують великої кількості закладів, які задовольняють потреби туриста у певному специфічному діапазоні, наприклад культурний туризм потребуе наявності на території певних об'єктів, які являють собою цінність та культурне надбання (археологічні знахідки, пам'ятки воєнної історії, архітектура); медичний туризм, зокрема, потребує наявності розвиненої медичної системи країни, кваліфікованих кадрів та коректно сформованого іміджу відповідної гілки медичного обслуговування (стоматологічний туризм, пологовий туризм).

Висновки i перспективи подальших досліджень. Отже, підводячи підсумок, потрібно відзначити, що незважаючи на велику кількість даних тлумачень понять «гостинність» та «індустрія гостинності» кожне із них описує сутність даних явищ і так чи інакше охоплює складові та чинники, що впливають на формування сектору гостинності в цілому.

Також варто відзначити, що на сучасному етапі на розвиток індустрії гостинності впливають дуже багато важливих як внутрішніх, так і зовнішніх чинників, які, власне, і формують сприятливе або несприятливе середовище для розвитку сфери гостинності в цілому, а також готельного господарства, зокрема, як важливого елемента в індустрії туризму.

Індустрія гостинності - це складна соціальноекономічна система із надання послуг 3 розміщення, харчування, перевезення, побутового обслуговування, дозвілля, розваг та інших послуг, а також реалізації товарів у закладах готельного i ресторанного бізнесу. Індустрія гостинності має тривалий історикоеволюційний розвиток, складну організацію, відіграє вагому роль в економіці на регіональному, державному та глобальному рівнях.

В умовах науково-технічного прогресу та стрімкого процесу комп'ютеризації абсолютно всіх сфер суспільства, доцільно було б звернути більше уваги саме на науково-технологічний фактор i його роль $\mathrm{y}$ розвитку індустрії гостинності.

\section{СПИСОК ВИКОРИСТАНИХ ДЖЕРЕЛ}

1. Офіційний сайт Всесвітньої туристичної організації [Електронний ресурс]. - Режим доступу: http://www.unwto.org - Назва з титул. екрана.

2. Кусков А.С. Гостиничное дело: учебное пособие./ А.С. Кусков. - М.: ИТК "Дашков и К", 2008.

3. Джанджугазова Е. А. Маркетинг в індустрії гостинності./ Е.А. Джанджугазова - М .: Академія, 2005.

4. Основы индустрии гостеприимства: Учебное пособие/ Д.И. Елканова, Д.А. Осипов, В.В. Романов, Е.В. Сорокина. - М.: Дашков и Ко, 2010. - с. 248

5. Браймер Р.А. Основы управления и индустрии гостеприимства/ Р.А. Браймер; пер. с англ. - М.: Аспект Пресс, 1995. - $326 \mathrm{c}$.

6. Зорин И.В. Энциклопедия туризма. Справочник / И.В. Зорин, В.А. Квартальнов. - М.: Финансы и статистика, 2003. $-368 \mathrm{c}$.

7. Соловьев Б. Л. Менеджмент гостеприимства / Б. Л. Соловьев, Л. А. Толстова - М.: РМАТ, 1997.

8. Котлер Ф. Маркетинг, гостеприимство, туризм: учебник. - 4 изд./ Ф. Котлер М.: ЮНИТИ-ДАНА, 2007 $1071 \mathrm{c}$.

9. Менеджмент туризма: учебник / А.Д. Чудновский, М.А. Жукова, Н.А. Зайцева.- М.: Федеральное агентство по туризму, 2015. - 576 c. ISBN 978-5-4365-0133-8

10. Воронкова Л.П. История туризма и гостеприимства : учеб. пособие./ Л.П. Воронкова. - М., 2004. - 304 с.

11. Dittmer G., Griffin G. Dimensions of the Hospitality Industry. An Introduction -N.Y.: Van No strand Reinhold, 1997. $573 \mathrm{p}$.

\section{REFERENCES}

1. Oficzijnij sajt Vsesvitnoyi turistichnoyi organizacziyi [Official site of World Tourism Organization]. unwto.org. Retrieved from: http://www.unwto.org. [in English].

2. Kuskov, A.S. (2008). Gostinichnoe delo: uchebnoe posobie [Hotel business: tutorial]. Moscow: Dashkov i Ko [in Russian].

3. Dzhandzhugazova, E. A. (2005). Marketing v industriyi gostinnosti [Marketing in the hospitality industry]. Moscow: Akademiya [in Russian].

4. Elkanova, D.I., \& Osipov, D.A., \& Romanov, V.V., \& Sorokina E.V. (2010). Osnovy industrii gostepriimstva: uchebnoe posobie [Hospitality industry basics: tutorial]/ Moscow: Dashkov i Ko [in Russian].

5. Brajmer, R.A. (1995). Osnovy upravleniya i industrii gostepriimstva [Management and hospitality industry basics]. Moscow: Aspekt Press [in Russian].

6. Zorin, I.V., \& Kvartal'nov, V.A. (2003). Encziklopediya turizma. Spravochnik [Encyclopedia of tourism. Directory]. Moscow: Finansy i statistika [in Russian]. 
7. Solovjev, B. L., \& Tolstova, L. A. (1997). Menedzhment gostepriimstva [Hospitality management]. Moscow: RMAT [in Russian].

8. Kotler, F. (2008). Marketing, gostepriimstvo, turizm: uchebnik [Marketing, hospitality, tourism: textbook]. Moscow: YuNITI-DANA [in Russian].

9. Chudnovskij, A.D., \& Zhukova, M.A., \& Zajceva N.A. (2015). Menedzhment turizma: uchebnik [Tourism management: textbook]. Moscow: Federal noe agentstvo po turizmu [in Russian].

10. Voronkova, L.P. (2004). Istoriya turizma i gostepriimstva: ucheb. posobie [History of tourism and hospitality: tutorial]. Moscow [in Russian].

11. Dittmer, G., Griffin, G. (1997). Dimensions of the Hospitality Industry. An Introduction. N.Y.: Van No strand Reinhold [in English].

Отримано 11.01.2020 